\title{
Dissemination of Salmonella Enteritidis by Experimentally-Infected Pigeons
}

\section{-Author(s)}

Albuquerque ÁH

Cardoso WM*

Teixeira RSC ${ }^{1}$

Lopes ES ${ }^{1}$

Sales RJPF ${ }^{1}$

Horn RV ${ }^{1}$

Rocha-e-Silva RC

Bezerra WGA ${ }^{1}$

Gomes-Filho VJR'

* Advisor of the Post Graduate Program in Veterinary Science

Laboratory of Ornithological Studies, Veterinary College, Ceará State University

\section{-Mail Adress}

Corresponding author e-mail address

Av. Rogaciano Leite, $200 \mathrm{Apt}^{\circ} 1303 \mathrm{BI}$.

Tulipe, Bairro Salinas, Fortaleza, CE, Brasil CEP 60810-786

Phone/Fax: (5585) 32411307 or (5585) 31019848 or (5585) 96549405

E-mail: william.maciel@uol.com.br and atillaholanda@hotmail.com

\section{-Keywords}

Inoculation, Pigeons, Salmonella Enteritidis.

\section{ABSTRACT}

Two groups of domestic pigeons (Columba livia) were experimentally infected orally with doses of $9.5 \times 10^{7}$ and $9.5 \times 10^{9} \mathrm{CFU} / \mathrm{mL}$ (group $A$ and $B$, respectively) of a Salmonella Enteritidis (SE) strain isolated from chickens. None of the used doses caused mortality of the inoculated birds; however, the pathogen was successfully recovered from the liver and spleen of group B birds on day 7 post-inoculation (dpi). Pathogen shedding, as evaluated through cloacal swabs, occurred in both groups until the $14^{\text {th }}$ day of observation $(p<0.05)$. Among all fecal samples collected from group $B(n=4)$, three different birds shed the pathogen in their feces, out of which two were positive on $3 \mathrm{dpi}$ and one on 7 dpi. The same number of fecal samples was evaluated in group $A$ and only one bird shed the pathogen, on 7 and $14 \mathrm{dpi}$. The concentration of the microorganism in the feces was lower in group $A$ than any sample from Group B. Salmonella Enteritidis isolated from chickens, when inoculated in pigeons, may be recovered from feces, cloacal swabs and organs, and these birds may contaminate poultry causing economic losses as well as posing a risk to the public health.

\section{INTRODUCTION}

The domestic pigeon (Columba livia) belongs to the order of Columbiformes and Columbidae family (Harrison, 1994). This bird rapidly reproduces in environments that offer sufficient shelter and large quantities of food available, but also lack of predators (Nunes, 2001). The domestic pigeon has a varied diet, which favors its multiplication, resulting in environmental disturbance where they inhabit due to the accumulation of feathers, feces and nest remains, leading to blockages of gutters or storm drain pipes (Nunes, 2001).

Concerning the public health, pigeons play an important role in the transmission of diseases that affect humans and domestic animals, such as toxoplasmosis (Karatepe et al. 2011), Newcastle disease (Alexander, 1985), aspergillosis (Pal, 1991) and salmonellosis (Sousa et al. 2010). According to Tauxe (1991), birds are considered the main source of salmonellosis dissemination in humans. Several authors have researched and isolated Salmonella spp. in the feces, cloacal swabs and organs of pigeons (Casanovas et al. 1995; Adesiyun et al. 1998; Toro et al. 1999; Passamonti et al. 2000; González-Acuña et al. 2007 and Sousa et al. 2010). Salmonella Enteritidis has been considered the serovar responsible for the largest number of outbreaks in humans and birds due to its wide distribution in nature, while the intestinal tract of animals are the main natural reservoir of this pathogen. Birds have a particularly important role in the spread of bacteria and may act as asymptomatic carriers, shedding the pathogen continuously in their feces (Franco, 2002). 
Albuquerque ÁH, Cardoso WM, Teixeira RSC, Lopes ES, Sales RJPF, Horn RV, Rocha-e-Silva RC,
Bezerra WGA, Gomes-Filho VJR

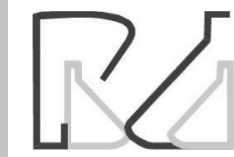

The mechanism by which the infection of Salmonella spp. develops in Columbidae birds is still poorly understood, especially regarding the Salmonella Enteritidis. Therefore this study aimed at evaluating the route and duration of shedding in the environment of Salmonella enterica serovar Enteritidis by its inoculation in domestic pigeons (Columba livia). The study was approved by the Ethics Committee for Animal Use in the registry number 10244384-0/22 (CEUA-UECE).

\section{MATERIAL AND METHODS}

\section{Experimental Groups}

In this experiment, 56 domestic pigeons (Columba livia) were obtained from the Laboratory of Ornithological Studies (LABEO). A fourth generation of pigeons in captivity, between six and twelve months of age was selected to the study. Pigeons were housed in pairs per cage and separated into two groups, which orally received two different inoculum concentrations of Salmonella Enteritidis: Group A (lower dose) and Group B (higher dose). The following variables were analyzed: SE concentration in the feces and in organs, frequency of positive swabs, organ and fecal samples. The inoculation and evaluation of the concentration of Salmonella Enteritidis in organs and feces was performed according to the methodology adopted by Oliveira et al. (2005).

\section{Inoculum Preparation}

A broth containing a Salmonella Enteritidis strain resistant to nalidixic acid (SENalr) was incubated overnight at a temperature of $37^{\circ} \mathrm{C}$, Birds in group A received $1 \mathrm{~mL}$ of the inoculum obtained from the culture SENal ${ }^{r}$ containing approximately $9.5 \times 10^{7}$ colony forming units $/ \mathrm{mL}$ (CFU/ $\mathrm{mL}$ ), whereas for group $B$, the culture was diluted by a factor of $10^{-3}$, containing approximately $9.5 \times 10^{9} \mathrm{CFU} / \mathrm{mL}$.

\section{Microbiological Evaluations}

On the $3,7,14,21,28$, and 35 day post-inoculation (dpi), fecal samples were collected from each cage, and four birds from each group were euthanized for spleen and liver collection for analysis of CFU and frequency of positive SENal'.

In the first step, the organs were individually homogenized and diluted in decimal series (1:10) in Phosphate Buffered Saline solution (PBS). The dilutions were plated on brilliant green agar (Oxoid CM265), containing nalidixic acid $(25 \mu \mathrm{g} / \mathrm{mL})$ and novobiocin
Dissemination of Salmonella Enteritidis by Experimentally-Infected Pigeons

(2 $\mu \mathrm{g} / \mathrm{mL}$ ) (BGNNov). The plates were incubated overnight at $37^{\circ} \mathrm{C}$ and the $\mathrm{CFU} / \mathrm{mL}$ were transformed into $\log _{10}$ for analysis. In the second step, a part from the remaining macerated organ samples was removed and incubated in selenite broth (CM395 Oxoid.) with novobiocin (40 mg/L) overnight at $37^{\circ} \mathrm{C}$, and then were plated on BGNNov and incubated at $37^{\circ} \mathrm{C}$ for 24 hours to enhance the growth of any potential SE cells in the organs, when CFU counting was not possible. The methodology used for the fecal samples was the same as the mentioned in the first stage of organ samples. Also, two cloacal swab samples were collected per week, and the methodology applied in the second stage of organ samples was used. Before starting the experiment, all birds were inspected according to Zancan et al.(2000) to confirm that they were free of Salmonella spp.

\section{Statistical Analysis}

The results of positive swab and fecal frequencies were compared using the $\chi 2$ test at a significance level of $p<0.05$.

\section{RESULTS AND DISCUSSION}

During the experiment, there was no mortality. The concentration of bacteria used in both inocula may have been insufficient to cause bird death (Rocha e Silva et al., 2013). However, the absence of mortality may be expected as literature often demonstrates that this serotype may infect the bird, but do not cause any visible clinical signs (Hogue et al., 1997). The infected birds may act as carriers of the disease, infecting other birds (Van Immerseel et al., 2004). Therefore, the age of the studied pigeons, which were six months or older, may be the most plausible explanation of the absence of mortality.

Studies performed with poultry show that infections by Salmonella Enteritidis of birds with more than one month of age rarely result in mortality (Suzuki, 1994). Ishola (2009) infected two groups of adult hens (33 wk) with different doses $\left(1.3 \times 10^{4}\right.$ and $\left.1.3 \times 10^{8} \mathrm{CFU}\right)$ of a SE strain previously isolated from chickens and did not report any mortality. The age-dependent immunity may favor the development of the immune system and the production of antibodies (Desmidt et al. 1998; Beal et al. 2004). In chickens, the susceptibility to the intestinal colonization by Salmonella spp. is higher during the first days of life, and reduces as the local intestinal microbiota develops (Nurmi \& Rantala, 1973; Pivnick et al. 1982). Adult birds are relatively resistant 
Albuquerque ÁH, Cardoso WM, Teixeira RSC, Lopes ES, Sales RJPF, Horn RV, Rocha-e-Silva RC, Bezerra WGA, Gomes-Filho VJR

to the systemic multiplication of SE, but may suffer colonization of the intestinal tract in the absence of clinical manifestations and remain as carriers, shedding the microorganism intermittently (Gast, 2003). Differently to what is observed in adult birds, SE is capable of causing high mortality in young birds. Gorham et al. (1991) inoculated in newly-hatched chicks $\left(1 \times 10^{7} \mathrm{CFU}\right)$ a SE strain isolated from a poultryrearing environment and verified that during seven days the mortality rate reached $21 \%(11 / 53)$.

When the concentration of SENal ${ }^{r}$ was evaluated in the collected organs, no bacterial growth was detected. However, SENal' was successfully recovered from the organs submitted to enrichment in Selenite-cystine broth followed by plating on BGN, which shows that the liver and spleen were invaded by the bacterium, albeit in a small number (Table 1).

Table 1 - Viable number $\left(\log _{10}\right)$ of Salmonella Enteritidis per gram of samples after inoculation

\begin{tabular}{|c|c|c|c|c|c|c|c|c|c|c|c|c|}
\hline & \multicolumn{2}{|c|}{3 days } & \multicolumn{2}{|c|}{7 days } & \multicolumn{2}{|c|}{14 days } & \multicolumn{2}{|c|}{21 days } & \multicolumn{2}{|c|}{28 days } & \multicolumn{2}{|c|}{35 days } \\
\hline Pigeon $\mathrm{N}^{\circ}$ & $\mathrm{L}$ & $S$ & $\mathrm{~L}$ & $S$ & $\mathrm{~L}$ & $S$ & $\mathrm{~L}$ & $S$ & $\mathrm{~L}$ & $S$ & $\mathrm{~L}$ & $S$ \\
\hline 1 & - & - & - & - & - & - & - & - & - & - & - & - \\
\hline 2 & - & - & - & - & - & - & - & - & - & - & - & - \\
\hline 3 & - & - & - & - & - & - & - & - & - & - & - & - \\
\hline 4 & - & - & - & - & - & - & - & - & - & - & - & - \\
\hline 5 & - & - & + & - & - & - & - & - & - & - & - & - \\
\hline 6 & - & - & - & - & - & - & - & - & - & - & - & - \\
\hline 7 & - & - & + & + & - & - & - & - & - & - & - & - \\
\hline 8 & - & - & + & + & - & - & - & - & - & - & - & - \\
\hline \multicolumn{13}{|c|}{ L: liver, S: Spleen; } \\
\hline \multicolumn{13}{|c|}{ Group A: Birds 1-4: inoculated with $1 \mathrm{~mL}$ of diluted broth overnight $(9.5 \times 107 \mathrm{CFU} / \mathrm{mL})$; } \\
\hline \multicolumn{13}{|c|}{ Group B: birds 5-8: inoculated with $1 \mathrm{~mL}$ of diluted broth overnight $(9.5 \times 109 \mathrm{CFU} / \mathrm{mL})$; } \\
\hline
\end{tabular}

Relative to the time required for the pathogen to successfully colonize the spleen and liver of pigeons, our results show that the recovery was only possible on 7 dpi. Gast et al. (2011) reported that both the frequency of microbial invasion and the recovery of the number of pathogen cells in the liver can vary significantly depending on the exposure dose administered. Oliveira et al. (2005) showed that in hens orally inoculated with a lower dose of Salmonella $\left(8.5 \times 10^{5} \mathrm{CFU} / \mathrm{mL}\right)$, the pathogen was recovered in the liver and the spleen only on $7 \mathrm{dpi}$, while in birds inoculated with the highest concentration $\left(8.5 \times 10^{8}\right.$ $\mathrm{CFU} / \mathrm{mL}$ ), it was recovered already did on $3 \mathrm{dpi}$. This indicates that both concentrations used in the present experiment may not have been sufficient to promote invasion of the liver and the spleen by the pathogen already on $3 \mathrm{dpi}$.

\section{Dissemination of Salmonella Enteritidis by Experimentally-Infected Pigeons}

Although scientific literature demonstrates that infectious bacterial load and bird age are important factors and may justify the absence of mortality or of the dissemination of the pathogen in the organism, other factors, such as genes associated to virulence of some Salmonella Enteritidis strains, anatomic differences between pigeons and other bird species, and immune status must be considered. The ability of Salmonella serotypes to cause systemic or localized infections or even to establish a carrier state is associated with host immunity and virulence-associated genes present in the bacteria (Cunningham-Rundles, 2004). Considering the anatomical aspects, differently from poultry, pigeons present rudimentary ceca. This may affect the presence of Salmonella in the organism because the predominant colonization site of salmonella is the ceca (Desmidt et al., 1997). Therefore, Gerlach (1994) asserts that birds that have rudimentary ceca or no ceca, such as psittacines, seem to be more susceptible to Salmonella sp. infection when compared with birds that have fully functional ceca. That may be explained by the presence of Gram-negative autochthonous anaerobic microorganisms present in the cecal flora, such as Bacteroides sp. and Spherophorus sp., which may function as natural antagonists of Salmonella sp. (Gerlach, 1994; Ritchie, 1994).

The results of the analysis of the frequency of cloacal swabs collected from both groups of pigeons showed that pathogen shedding occurred up to $14 \mathrm{dpi}$ in both groups, and that the frequency of bacteria shedding in group $B\left(9.5 \times 10^{9} \mathrm{CFU} / \mathrm{mL}\right)$ was significantly higher ( $p$ $<0.05)$ when compared with group $A\left(9.5 \times 10^{7} \mathrm{CFU} /\right.$ $\mathrm{mL}$ ) only on 3 and $7 \mathrm{dpi}$ (Table 2).

Table 2 - Absolute $(\mathrm{n})$ and relative (\%) frequencies of swabs positive for Salmonella Enteritidis during the postinoculation period

\begin{tabular}{lcccc}
\hline & \multicolumn{2}{c}{$\begin{array}{c}\text { Dose/CFU/mL } \\
9.5 \times 10^{7}\end{array}$} & \multicolumn{2}{c}{$\begin{array}{c}\text { Dose/CFU/mL } \\
9.5 \times 10^{9}\end{array}$} \\
\hline $\mathrm{N}$ & $(\%)$ & $\mathrm{N}$ & $(\%)$ \\
\hline $3 \mathrm{dpi}$ & $2 / 24^{\mathrm{a}}$ & 8.3 & $8 / 24^{\mathrm{b}}$ & 33.3 \\
\hline $5 \mathrm{dpi}$ & $2 / 20^{\mathrm{a}}$ & 10.0 & $8 / 20^{\mathrm{b}}$ & 40.0 \\
$7 \mathrm{dpi}$ & $5 / 20$ & 25 & $10 / 20$ & 50.0 \\
$14 \mathrm{dpi}$ & $2 / 16$ & 12.5 & $1 / 16$ & 6.3 \\
$21 \mathrm{dpi}$ & $0 / 8$ & 0 & $0 / 8$ & 0 \\
$28 \mathrm{dpi}$ & $0 / 8$ & 0 & $0 / 8$ & 0 \\
$35 \mathrm{dpi}$ & $0 / 4$ & 0 & $0 / 4$ & 0 \\
\hline
\end{tabular}

The absence of major findings with swabs in this study appears to be due to false negatives. Literature results with paratyphoid infections suggest this possibility, such as in Gast (2003), who worked with chickens and reported that, in sub-clinical infections, 
Albuquerque ÁH, Cardoso WM, Teixeira RSC, Lopes ES, Sales RJPF, Horn RV, Rocha-e-Silva RC,

Bezerra WGA, Gomes-Filho VJR

infected chickens continued harboring the bacterium in their bodies and shedding it in feces for a variable period of time. The use of a strain that is not adapted to pigeons also seems to have influenced the low frequency of Salmonella in samples obtained from cloacal swabs. The use of strains adapted to the species under study can result in higher rates of fecal excretion. Ishola (2009) inoculated adapted strains in laying hens (10-8 CFU) and found that the highest frequency of positive results for Salmonella in feces within five weeks of experimental evaluation was $100 \%$ and the lowest was $40 \%$. This demands greater efficacy of Salmonella control programs, not only by adopting the method of cloacal swab incubation as a determinant, but also by increasing the amount and the frequency of sample collection in order to know the real status of the birds (Muir et al., 1998).

Relative to the frequency of SENal' fecal shedding, the group of pigeons inoculated with the lower concentration started shedding only on 7 dpi $\left(1.5 \times 10^{4}\right)$, and continued until $14 \mathrm{dpi}\left(2 \times 10^{5}\right)$. Among the pigeons inoculated with the higher concentration of SENal', birds from two cages started shedding on 3 dpi $\left(1.9 \times 10^{7}\right.$ and $\left.2 \times 10^{9}\right)$ and from one cage on $7 \mathrm{dpi}$ $\left(1 \times 10^{7}\right)$, but no cells were counted on the other days of observation (Table 3).

Table 3 - Recovery of Salmonella Enteritidis in feces of pigeons post-inoculation (CFU/g)

\begin{tabular}{ccccccc}
\hline & $3 \mathrm{dpi}$ & $7 \mathrm{dpi}$ & $14 \mathrm{dpi}$ & $21 \mathrm{dpi}$ & $28 \mathrm{dpi}$ & $35 \mathrm{dpi}$ \\
\cline { 2 - 7 } Cages & CFU & CFU & CFU & CFU & CFU & CFU \\
\hline 2 & 0 & 0 & 0 & 0 & 0 & 0 \\
5 & 0 & 0 & 0 & 0 & 0 & 0 \\
7 & 0 & 0 & 0 & 0 & 0 & 0 \\
10 & 0 & $1.5 \times 10^{4}$ & $2 \times 10^{5}$ & 0 & 0 & 0 \\
16 & 0 & 0 & 0 & 0 & 0 & 0 \\
18 & 0 & $1 \times 10^{7}$ & 0 & 0 & 0 & 0 \\
19 & $1.9 \times 10^{5}$ & 0 & 0 & 0 & 0 & 0 \\
23 & $2 \times 10^{9}$ & 0 & 0 & 0 & 0 & 0 \\
\hline
\end{tabular}

Group A: cages 2, 5, 7 and 10: pigeons inoculated with $1 \mathrm{~mL}$ of a diluted broth $(9.5$ x 107 CFU/mL); Group B: cages 16, 18, 19 and 23: pigeons inoculated with $1 \mathrm{~mL}$ of diluted broth $(9.5 \times 109 \mathrm{CFU} / \mathrm{mL})$

When a microorganism is detected in the feces, the colonization of a part or all of the digestive tract may be implied. Barrow et al. (1988) said that the colonization of bacteria in the digestive tract can be observed through the excretion in feces and the detection of the pathogen is carried out by incubation of feces or cloacal swabs.

Since the strain used in this experiment is not adapted to the inoculated species, the doses

\section{Dissemination of Salmonella Enteritidis by Experimentally-Infected Pigeons}

administered in this study do not seem to be sufficient to generate a greater systemic dissemination, as no bird presented any significant quantity or frequency of the bacterium, considering all the pigeons assessed. Gast (2003) stated that inoculated chickens and turkeys can shed paratyphoid Salmonella spp. during the first two weeks after experimental oral infection and that the bacterium can be isolated from the intestinal tract; however, there may be a high percentage of noncontaminated feces.

The short period of fecal pathogen shedding presented by the pigeons maybe explained by the absence or temporary colonization of the intestinal tract by the the pathogen (Barrow et al. 1988). Another hypothesis for the decline in the frequency of SENalr fecal shedding is that the pigeons may have been able to reduce the level of systemic infection probably by humoral immune response (Hassan et al. 1991; Muir et al. 1998). However, even with low quantities of contaminated feces, González-Acunã et al. (2007) argued that both dried and fresh pigeon feces pose a high risk of Salmonella transmission to humans, particularly children, the elderly, or immunecompromised individuals, as well as domestic animals.

The doses administrated to pigeons, although relatively low considering the results found in the organs, cloacal swabs and feces until $35 \mathrm{dpi}$, show that these birds can excrete Salmonella Enteritidis strains that not adapted to their species. Because pigeons have access to rural and urban environments, they may enter commercial poultry houses, defecate on the litter and cause major economic losses and public health issues. Experiments with chickens on the litter showed that reinfection may play an important role in the persistence of the infection (Gast, 2000; Beal et al. 2004).

In conclusion, this study shows that Salmonella Enteritidis isolated from chickens, when inoculated in pigeons, may be recovered from feces, cloacal swabs and organs. This demonstrates that pigeons may play a role in the dissemination of this pathogen, because they may shed it when defecating on the litter in commercial poultry houses or in feed production facilities, causing economic losses as well as posing a risk to public health.

\section{ACKNOWLEDGMENTS}

The authors thank Conselho Nacional de Pesquisa e Desenvolvimento (CNPq) and the Laboratory of Ornithological Studies (LABEO/FAVET/UECE) for their support. 


\section{REFERENCES}

Adesiyun AA, Seepersadsingh N, Inder L, Caesar K. Some bacterial enteropathogens in wildlife and racing pigeons from Trinidad. Journal Wildlife Diseases 1998;34(1):73-80.

Alexander DJ, Russell PH, Parsons G, Abu Elzein EME, Ballouh A, Cernik K et al. Antigenic and biological characterization of avian paramyxovirus type-1 isolates from pigeons: an international collaborative study. Avian Pathology 1985;14(3):365-376.

Barrow PA, Simpson JM, Lovell MA. Intestinal colonisation in the chicken by food-poisoning Salmonella serotypes: microbial characteristics associated with faecal excretion. Avian Pathology 1988;17(3):571-588.

Beal RK, Wigley P, Powers C, Hulme SD, Barrow PA, Smith AL, Age at primary infection with Salmonella enterica serovar Typhimurium in the chicken influences persistence of infection and sub sequent immunity to re-challenge. Veterinary Immunology and Immunopathology 2004; 100(3-4):151-164

Casanovas L, Simon DE, Ferrer M, Arques MJ, Monzón G. Intestinal carriage of campylobacters, salmonellas, yersinias and listerias in pigeons in the city Barcelona. Journal of Applied Bacteriology 1995;78(1):11-13.

Cunningham-Rundles S. The effect of aging on mucosal host defense. Journal of Nutrition, Health \& Aging 2004;26:20-25

Desmidt M, Ducalette R, Mast J, Goddeeris BM, Kaspers B, Haesebrouck F. Role of the immune system in Salmonella Enteritidis phage types four infection in chickens. Veterinary Immunology and Immunopathology 1998;63(4):355-355

Franco BDGM. Microbiologia dos alimentos. São Paulo: ATHENEU; 2002. p. 58-60.

Gast RK. Salmonella enteritidis in eggs and egg products: Assessing and understanding the risks and responses. In: Egg nutrition and biotechnology. 2nd ed. Columbus: M.A.C. Associates; 2000. p.431-40.

Gast RK. Salmonella Infections. In: Saif YM, editor. Diseases of poultry. 11th ed. Ames: lowa State Press; 2003. p.567-613.

Gast RK, Guraya R, Guard J, Holt PS. Frequency and Magnitude of Internal Organ Colonization Following Exposure of Laying Hens to Different Oral Doses of Salmonella enteritidis. International Journal of Poultry Science $2011 ; 10(4): 325-331$

González-Acuña D, Silva FG, Moreno LS, Cerda FL, Donoso SE, Cabello JC, López JM. Detección de algunos agentes zoonóticos en la paloma doméstica (Columba livia) en la ciudad de Chillán, Chile. Revista chilena de Infectología 2007;24(3):199-203.

Gerlach H. Bacteria. In: Ritchie, Harrison, Harrison, editors. Avian medicine: principles and application. Lake Worth: Wingers Publishing Inc; 1994. p.949-983

Gorham SL, Kadavil K, Lambert H, Vaughan E, Pert B, Abel J. Persistence of Salmonella enteritidis in young chickens. Avian Pathology $1991 ; 20(3): 433-437$

Harrison C, Greensmith A. Aves del mundo. Barcelona: Ediciones Omega; 1994. p. 159

Hassan JO, Mockett APA, Catty D, Barrow PA. Infection and reinfection of chickens with Salmonella Typhimurium: bacteriology and immune responses. Avian Diseases 1991;35(4):809-819.

Hogue A, White P, Guard-Petter J, Schlosser W, Gast R, Ebel E, Farrar J, Gomez T, Madden J, Madison M, McNamara AM, Morales R, Parham D, Sparling P, Sutherlin W, Swerdlow D. Epidemiology and control of

\section{Experimentally-Infected Pigeons}

egg associated Salmonella enteritidis in the United States of America Revue Scientifique et Technique 1997;16:542-553.

Ishola OO. Effects of challenge dose on faecal shedding of Salmonella enteritidis in experimental infected chickens. African Journal of Biotechnology 2009;8(7):1343-1346.

Karatepe M, Kılıc S, Karatepe B, Babur C. Prevalence of Toxoplasma gondii Antibodies in Domestic (Columba livia domestica) and Wild (Columba livia livia) Pigeons in Niğde region, Turkey. Turkiye Parazitol Derg 2011;35(1):23-26

Muir WI, Bryden WL, Husband A J. Comparison of Salmonella typhimurium challenge models in chickens. Avian Diseases 1998;42(2):257-264.

Nunes VFP. Manejo de pombas urbanas. I Fórum do controle de pombos em área urbana;2001; São Paulo, SP. Brasil: Centro de Controle de zoonoses; 2001. p.21

Nurmi E, Rantala M. New aspects of Salmonella infection in broiler production. Nature 1973; 241(5386):210-211

Oliveira GH, Berchieri Junior A, Fernandes AC. Experimental infection of laying hens with Salmonella enterica serovar Gallinarum. Brazilian Journal of Microbiology 2005;36(1):51-56

Pal M. Disseminated Aspergillus terrus infection in a caged pigeon. Mycopathologia 1991; 119(3):137-139

Passamonti F, Asdrubali G, Proietti P, Rossi E, Battistacci L. Agents of zoonosis in wild city pigeon and in meat pigeon. 38th Convegno della Societa Italiana di Patologia Aviare "Riposta inmunitaria in funzione di eta e tipo genetico; 1999 Set 30 Ott 1; Forli. Italy. Selezioneveterinaria. p. $795-803$

Pivnick H, Blanchfield B, Rigby C, Ormsby E. Comparison of fresh feces with lyophilized and frozen cultures of feces as inocula to prevent Salmonella infection in chicks. Journal Food Protect 1982; 45(13):1188-1194.

Ritchie BW, GJ Harrison, Harrison LR. Avian medicine: principles and application. Lake worth: Wingers Publishing Inc; 1994. p.1384.

Rocha-e-Silva RC, Cardoso WM, Teixeira RSC, Albuquerque ÁH; Horn RV, Cavalcanti CM. Salmonella Gallinarum virulence in experimentallyinfected Japanese quails (Coturnix japonica). Brazilian Journal of Poultry Science 2013;15(1):39-45.

Sousa E, Berchieri Júnior A, Pinto AA, Machado RZ, Carrasco AOT, Marciano JA, Werther K. Prevalence of Salmonella spp. Antibodies to Toxoplasma gondii, and Newcastle Disease Virus in Feral Pigeons (Columba livia) in the City of Jaboticabal, Brazil. Journal of Zoo and Wildlife Medicine 2010;41(4):603-607.

Suzuki S. Pathogenicity of Salmonella enteritidis in poultry. International Journal of Food Microbiology 1994;21(1-2):89-105.

Tauxe RV. Salmonella: a post modem pathogen. Journal Food Protection 1991;54(7):563-568.

Toro H, Saucedo C, Borie C, Gough R, Alcaíno H. Health status of free-living pigeons in the city of Santiago. Avian Pathology 1999;28(6):619-23.

Van Immerseel F, De Buck J, Pasmans F, Bohez L, Boyen F, Haesebrouck F Ducatelle R. Intermittent long-term shedding and induction of carrier birds after infection of chickens early posthatch with a low or high dose of Salmonella Enteritidis. Poultry Science 2004;83(11);1911-1916.

Zancan FT, Berchieri Jr. A, Fernandes SA, Gama N. M. S. Q. Salmonella spp. investigation in transport boxes of day-old birds. Brazilian Journal of Microbiology 2000;31(3):230-232. 